\title{
PREVALENSI ANEMIA PADA ANAK 2-4 TAHUN DI DKI JAKARTA SERTA FAKTOR RISIKONYA
}

\author{
Iman Sumarno'; Vita Kartika' dan Edwi Saraswati ${ }^{1}$ \\ Puslitbang Gizi dan Makanan Dep.Kes. RI
}

\begin{abstract}
Anemia in young children causes retardation in growth and development, and low immunity. The crisis that hit Indonesia, decreased socio- economic status of the populations and public services. Hellen Keller International reported high prevalance of anemia in young children in poor areas of Indonesia. Aware about the severe consequences of anemia, Provincial Health Office of Jakarta in 2002 assesed the magnitude of anemia in children aged 2-4 year in Jakarta. The survey was planned to represent each areas of Jakarta, namely West Jakarta, Central Jakarta, East Jakarta, South Jakarta, North Jakarta, and district of Pulau Seribu. Thirty clusters were systematically drawn in each cluster 7 children aged 2-4 years were systematically random in each cluster. It was found that the education level of parents were relatively low: among mother of the samples $85 \%$ were house wivesand $38 \%$ of the father were in informal sectors. The prevalance of anemia of children aged 2-4 years was $26,8 \%$. It ranges from $13.5 \%$ in South Jakarta to the highest $51.3 \%$ in Pulau Seribu. The risk factors of anemia for children were underweight and ever defecate worm with increased risk 1.5 and 1.9 ti. On the other named comsumption of vitamin A capsules more then 3 times. is protective agains anemia as low as $27 \%$. Having parents or working in company reduced risk of anemia by $33 \%$.
\end{abstract}

Keywords: anemia, risk factors

\section{PENDAHULUAN}

$\mathrm{S}$ udah diketahui bahwa anemia pada balita dapat berakibat pada rendahnya kekebalan terhadap penyakit, ter-hambatnya kemampuan motorik, tumbuh-kembang, dan terganggunya kecerdasan. Rendahnya kekebalan terhadap penyakit infeksi ditemui pada balita yang menderita kekurangan zat besi (1). Balita yang menderita anemia umumnya cepat lelah karena kekurangan pasokan oksigen ${ }^{(2)}$. Cepat lelah membuat anak menjadi kurang bergerak dan akibatnya otot menjadi kurang terlatih. Zat besi diperlukan untuk memperbanyak jumlah dan meningkatkan ukuran sel tubuh. Kekurangan zat besi mengakibatkan pertambahan jumlah sel terhambat dan pembesaran ukuran sel juga terhambat. Gangguan kecerdasan selain dipengaruhi oleh terhambatnya pertambahan sel otak, juga anak anemia umumnya mempunyai tingkat konsentrasi belajar yang rendah. Dengan kata lain anemia pada balita dapat menurunkan kualitas sumber daya manusia. Masalah anemia sudah muncul pada bayi. Secara teoritis balita terutama dari bayi prematur akan menderita anemia. Bayi yang lahir normal mempunyai persediaan zat besi yang cukup sampai 6 bulan dan pada bayi premature persediaan zat besi lebih rendah lagi. Setelah lahir zat besi dari air susu ibu (ASI) tidak mencukupi kebutuhan. Sedangkan makanan bayi terutama yang berasal dari serealia tidak dapat memasok zat besi yang cukup karena bioavailabilitas working in government sangat rendah ${ }^{(3)}$. Apriyanto $\mathrm{R}$ dkk ${ }^{(4)}$, menunjukkan bahwa makanan pendamping air susu ibu (MP-ASI) 
tradisional di Indonesia sangat kurang zat gizi mikro. Masalah anemia sejak awal kehidupan memberikan dampak yang lebih parah bila tidak ditanggulangi. Mengingat akibat yang sangat merugikan bagi individu, keluarga, maupun negara, maka anemia pada balita harus ditanggulangi dengan cara yang tepat. Untuk perencanaan penanggulangan yang terarah diperlukan informasi tentang kedalaman dan besarnya masalah anemia pada balita. Pada saat ini informasi prevalensi anemia pada balita yang tersedia adalah pada gambaran nasional dari Survei Kesehatan Nasional, yang tidak menggambarkan masalah anemia balita pada tingkat provinsi, atau kabupaten, serta survei-survei kecil yang kurang menggambarkan wilayah. Untuk perencanaan program di tingkat provinsi dan kabupaten/kota, DKI Jakarta telah melakukan survei anemia pada balita.

Penelitian ini secara umum bertujuan untuk mendapatkan informasi tingkat prevalensi anemia pada balita di DKI Jakarta, secara khusus penelitian ini bertujuan untuk (1).mendapatkan prevalensi anemia pada balita di tiap wilayah di Propinsi DKI Jakarta, (2).mempelajari prevalensi anemia pada balita menurut umur, dan (3) mempelajari faktor risiko anemia pada balita di Jakarta.

\section{BAHAN DAN CARA}

Disain penelitian ini adalah survei cepat yang dirancang dengan disain potong lintang. Penelitian dilakukan di 5 daerah Kota di DKI Jakarta dan Kabupaten Kepulauan Seribu. Karena keterbatasan dana dan tenaga serta waktu maka di Kepulauan Seribu hanya diambil Pulau Kelapa. Survei ini tidak dimaksud untuk menggambarkan representatif Kepulauan Seribu.

Populasi studi adalah balita yang tinggal di wilayah DKI Jakarta. Perhitungan besar sampel dilakukan dengan rumus:

$$
N=\frac{\left(Z_{\alpha 0,05}\right)^{2} X(p x q)}{\Delta^{2}} X \mathrm{De}
$$

Dimana $Z$ dengan interval kepercayaan $95 \%=1,96$

P optimal $=0,5$ dan $q=1-p=0,5$

$\Delta=$ perbedan yang dapat diterima dalam hal ini $0,1(10 \%)$

$\mathrm{De}=$ disain efek adalah kelipatan sidik ragam sebagai akibat penggunaan disain klaster, dalam hal ini digunakan nilai 2.

Berdasarkan rumus dan beberapa parameter diatas maka sampel yang diperlukan adalah 192 dibulatkan menjadi 210. Masing-masing klaster $=210 / 30=7$ Balita.

Klaster adalah RW wilayah kota, dan kemungkinan Posyandu di kabupaten Kepulauan Seribu. Sesuai dengan prinsip sampel semakin tersebar semakin baik maka klaster disebar di setiap kecamatan. Jumlah klaster di setiap kecamatan adalah proporsional dengan perbandingan jumlah RW di masing-masing kecamatan. Jumlah klaster di kecamatan $\mathrm{A}=$ (Jumlah RW di kecamatan A/Jumlah RW di wilayah kota/kabupaten) X 30. Klaster ditentukan dengan acak sistematik. Di setiap klaster terpilih ditentukan secara acak 1 Posyandu. Di setiap Posyandu sampel dipilih secara acak 7 Balita, sebagai sampel.

\section{Data dan cara pengumpulannya}

Kadar $\mathrm{Hb}$ darah diambil dari darah ujung jari oleh tenaga terlatih. Analisis kadar $\mathrm{Hb}$ darah dilakukan dengan metode Cyanmeth.

Berat badan diukur oleh ahli gizi dengan timbangan dacin. Tinggi/panjang badan diukur dengan microtoise. Data kecacingan dan sosial ekonomi rumahtangga dikumpulkan dengan wawancara. Keadaan rumah dan lingkungannya dilakukan dengan pengamatan dan wawancara. Data 
morbiditas anak dikumpulkan dengan cara wawancara dan pemeriksaan klinis.

\section{Pengolahan data}

Pengecekan data/pemeriksaan kelengkapan dan kebenaran data dilakukan oleh supervisor di lapangan. Dilakukan uji kebenaran data dengan mencetak $10 \%$ data secara acak dibandingkan dengan data pada formulir.

Prevalensi anemia ditentukan dengan batas anemia pada balita menurut WHO yaitu kadar $\mathrm{Hb}<=11 \mathrm{~g} / \mathrm{L}$ sebagai batas anemia. Batas KEP yang digunakan adalah berat badan menurut umur $(\mathrm{BB} / \mathrm{U})<=-2 \mathrm{Z}$. Pekerjaan bapak dikelompokkan menjadi kelompok pegawai, buruh dan pedagang kecil dan pekerjaan sector informal. Setiap kelompok pendidikan dan pekerjaan dibuat peubah boneka (dummy), pada saat analisis regresi logistik.

\section{Analisis data}

Analisis data dilakukan secara deskriptif dengan univariate dan bivariate
(Khi kuadrat), dan multivariate regresi logistik ganda.

\section{HASIL DAN BAHASAN}

\section{Distribusi umur sampel}

Banyak masalah kesehatan dan gizi yang prevalensi maupun keparahannya dipengaruhi oleh umur. Sebagai contoh usia dua tahun merupakan saat mulai tidak lagi mendapat ASI. Dengan demikian pasokan zat gizi sepenuhnya hanya dari makanan yang dikonsumsinya. Kelompok ini juga sudah tidak mendapat makanan pendamping ASI. Distribusi sampel menurut umur disajikan pada tabel 1. Kelompok usia kurang dari 2 tahun hanya $1,9 \%$, walaupun pada saat terliput sudah diusahakan umur 24 tahun.

Kelompok usia 2 tahun terliput 31,9\%, tiga tahun $39,1 \%$ dan usia kelompok 4 tahun sampai 4 tahun 11 bulan terliput 27,1 $\%$. Distribusi ini hampir merata di seluruh wilayah DKI Jakarta.

Tabel 1

Distribusi Umur Sampel

\begin{tabular}{|l|c|c|c|c|c|}
\hline \multirow{2}{*}{ Wilayah } & \multicolumn{4}{|c|}{ Kelompok umur dalam bulan } & \multirow{2}{*}{ Total sampel } \\
\cline { 2 - 5 } & $<24$ & $24-35$ & $36-47$ & $>47$ & \\
\hline Jakarta Utara & 1.6 & 31.6 & 37.3 & 29.5 & 195 \\
\hline Jakarta Pusat & 1.6 & 30.3 & 41.7 & 26.3 & 211 \\
\hline Jakarta Selatan & 2.5 & 35.5 & 40.7 & 21.3 & 207 \\
\hline Jakarta Barat & 1.6 & 32.7 & 38.4 & 27.5 & 204 \\
\hline Jakarta Timur & 0.7 & 31.0 & 45.1 & 23.3 & 213 \\
\hline Pulau Seribu & 3.5 & 29.7 & 30.2 & 36.6 & 156 \\
\hline Total & 1.9 & 31.9 & 39.1 & 27.1 & 1186 \\
\hline
\end{tabular}

Keadaan sosial ekonomi rumahtangga sampel

Tingkat pendidikan orang tua sampel

Tingkat pendidikan ibu dan bapak anak balita sampel relatif sama (lihat tabel 2). Puncak (mode) tingkat pendidikan ibu berada pada lulus SLTA $(31,2 \%)$ dan mode tingkat pendidikan bapak berada pada tingkat yang sama yaitu lulus SLTA (44\%). Baik bapak maupun ibu masih ada yang tidak pernah sekolah dan tidak lulus SD. Pada ibu proporsinya mencapai 11\% sedangkan pada bapak hanya $4 \%$. 
Tabel 2

Tingkat Pendidikan Ibu dan Bapak Balita

\begin{tabular}{|l|r|r|r|r|}
\hline \multirow{2}{*}{ Tingkat Pendidikan } & \multicolumn{2}{|c|}{ lbu } & \multicolumn{2}{c|}{ Bapak } \\
\cline { 2 - 5 } & \multicolumn{1}{|c|}{$\mathrm{N}$} & persen & \multicolumn{1}{c|}{ N } & persen \\
\hline Tidak sekolah & 34 & 2.9 & 12 & 1.0 \\
Tidak lulus SD & 94 & 8.3 & 40 & 3.4 \\
Lulus SD & 319 & 26.9 & 266 & 22.4 \\
Lulus SLTP & 312 & 26.3 & 282 & 23.8 \\
Lulus SLTA & 370 & 31.2 & 522 & 44.0 \\
Lulus Akademi & 40 & 3.4 & 27 & 2.3 \\
Lulus Universitas & 13 & 1.1 & 37 & 3.1 \\
\hline Jumlah & 1186 & 100.0 & 1186 & 100.0 \\
\hline
\end{tabular}

\section{Pekerjaan orang tua sampel}

Sesuai dengan tingkat pendidikan di atas maka jenis pekerjaan ibu dan bapak balita berada pada pekerjaan dengan tingkat pendapatan menengah ke bawah (Tabel 3). Sebagian besar $(84,6 \%)$ ibu sampel adalah ibu rumahtangga yang tidak bekerja untuk mendapatkan uang. Ibu yang bekerja di luar rumah proporsinya relatif kecil. Sebesar
2,5\% ibu sampel bekerja sebagai buruh pada perusahaan, $5 \%$ sebagai pedagang kecil, $4 \%$ sebagai pegawai swasta. Sebesar $0,7 \%$ dari ibu balita adalah pegawai negeri. Ibu yang bekerja di sektor jasa dan informal besarnya 3\%. Bapak yang merupakan tulang punggung rumahtangga sebagian besar $(38,4 \%)$ bekerja pada kegiatan jasa informal, dari angkutan, jahit dan lain-lain.

Tabel 3

Pekerjaan Ibu dan Bapak Balita

\begin{tabular}{|l|r|r|r|r|}
\hline \multirow{2}{*}{ Macam pekerjaan } & \multicolumn{2}{|c|}{ lbu } & \multicolumn{2}{c|}{ Bapak } \\
\cline { 2 - 5 } \multicolumn{1}{|c|}{} & $\mathrm{N}$ & persen & $\mathrm{N}$ & \multicolumn{1}{c|}{ persen } \\
\hline Ibu rumahtangga & 1003 & 84.6 & - & - \\
Buruh & 30 & 2.5 & 266 & 22.4 \\
Pedagang kecil & 61 & 5.1 & 91 & 7.7 \\
Pegawai swasta & 49 & 4.1 & 313 & 26.4 \\
Pegawai negeri & 8 & 0.7 & 60 & 5.1 \\
Jasa sektor informal & 35 & 3.0 & 456 & 38.4 \\
\hline Total & 1186 & 100.0 & 1186 & 100.0 \\
\hline
\end{tabular}

Sebesar 22,4 \% bapak bekerja sebagai buruh dan pada proporsi yang tidak jauh berbeda (26,4\%) sebagai pegawai perusahaan swasta. Hanya $5 \%$ dari bapak balita sampel bekerja sebagai pegawai negeri. Pekerjaan yang dilakukan bapak balita memberikan gambaran bahwa bapak mempunyai tingkat pendapatan yang tidak terlalu tinggi.

\section{Morbiditas balita}

Dalam pengumpulan data penyakit anak dilakukan dengan dua cara yaitu dengan wawancara kepada ibunya dan pemeriksaan klinis. Hal ini dilakukan karena dalam survey ini tidak dilakukan pemeriksaan tinja. Pemeriksaan klinis tidak dapat dilakukan untuk penderita cacingan. Karena itu pengumpulan data penyakit cacingan dilakukan wawancara. 


\section{Keadaan klinis menurut pemeriksaan dokter}

Berdasarkan pemeriksaan klinis ditemukan $41,4 \%$ anak balita dalam keadaan sehat, dengan kata lain sebagian besar $(58,6$ $\%$ ) justru sedang sakit (tabel 4). Proporsi balita yang menderita penyakit saluran pernafasan jauh lebih tinggi dari balita yang menderita infeksi saluran pencernaan.

Tabel 4

Keadaan Klinis Balita Hasil Pemeriksaan Klinis

\begin{tabular}{|l|c|c|c|c|}
\hline \multirow{2}{*}{ Wilayah } & \multirow{2}{*}{ sehat } & \multicolumn{3}{|c|}{ Sakit } \\
\cline { 3 - 5 } & & pernafasan & pencernaan & Lain-lain \\
\hline Jakarta Utara & 53.5 & 23.3 & 3.0 & 20.3 \\
Jakarta Pusat & 34.1 & 26.5 & 0.9 & 38.4 \\
Jakarta Selatan & 55.6 & 27.1 & 0.0 & 17.4 \\
Jakarta Barat & 28.4 & 29.9 & 2.5 & 39.7 \\
Jakarta Timur & 31.1 & 32.5 & 1.0 & 35.9 \\
Pulau Seribu & 47.4 & 25.6 & 0.6 & 26.1 \\
\hline \multicolumn{1}{|c|}{ Jumlah } & 41.4 & 27.6 & 1.3 & 29.8 \\
\hline
\end{tabular}

Proporsi balita yang menderita infeksi saluran pernafasan relatif merata di seluruh wilayah DKI Jakarta, dengan prevalensi terendah $23,3 \%$ di Jakarta Utara dan tertinggi $32,5 \%$ di Jakarta Timur. Kasus infeksi pencernaan sangat rendah, hal ini karena kejadian sakit saluran pernafasan dan pencernaan sangat dipengaruhi musim.

\section{Hasil wawancara mengenai cacingan}

Semua ibu melaporkan bahwa anaknya pernah mengeluarkan cacing dalam sebulan terakhir (Tabel 5).Sebanyak 10,1 \% ibu melaporkan anaknya mengeluarkan cacing 1 kali dalam 1 bulan terakhir, sedangkan sisanya tidak atau tidak tahu. Ibu di Pulau Kelapa paling banyak melaporkan anaknya keluar cacingan dalam 1 bulan. Angka ini mungkin lebih rendah dari sebenarnya, karena ada kasus ibu yang tidak terdeteksi.

Tabel 5

Kasus Balita Keluar Cacing

\begin{tabular}{|l|c|c|c|}
\hline \multirow{2}{*}{ Wilayah } & \multicolumn{3}{|c|}{ Keluar Cacing } \\
\cline { 2 - 4 } & \multicolumn{1}{|c|}{ ya } & tidak & $\mathrm{n}$ \\
\hline Jakarta Utara & 6.0 & 94.0 & 195 \\
Jakarta Pusat & 4.9 & 95.1 & 211 \\
Jakarta Selatan & 4.8 & 95.2 & 207 \\
Jakarta Barat & 1.0 & 99.0 & 204 \\
Jakarta Timur & 7.5 & 92.5 & 213 \\
Pulau Seribu & 40.2 & 59.8 & 156 \\
DKI Jakarta & 10.1 & 89.9 & 1186 \\
\hline
\end{tabular}

\section{Prevalensi kurang energi protein (KEP)}

Kurang energi protein diukur dengan berat badan menurut umur, menggambarkan gambaran kombinasi akumulasi sejak lahir sampai saat ini dan kondisi akut.

Sebanyak $30,7 \%$ balita di Propinsi DKI Jakarta menderita berat badan kurang 
menurut umur (tabel 6). Bila kita lihat per wilayah, tampaknya wilayah Jakarta Selatan yang mempunyai balita dengan prevalensi KEP terendah yaitu $23,3 \%$.

Tabel 6

Prevalensi KEP Balita Menurut Wilayah

\begin{tabular}{|l|c|c|}
\hline \multicolumn{1}{|c|}{ Wilayah } & N & $\begin{array}{c}\text { Kurang gizi } \\
(<=-2 \text { Z score })\end{array}$ \\
\hline Jakarta Utara & 181 & 32.0 \\
Jakarta Pusat & 211 & 27.5 \\
Jakarta Selatan & 193 & 23.3 \\
Jakarta Barat & 211 & 33.2 \\
Jakarta Timur & 206 & 29.1 \\
Pulau Seribu & 156 & 41.2 \\
DKI Jakarta & 1130 & 30.7 \\
\hline
\end{tabular}

Sedangkan wilayah yang tertinggi prevalensinya 41,2 \% adalah Pulau Seribu. Dilihat dari prevalensi berat badan menurut umur tampaknya anak balita DKI sangat banyak yang mengalami gangguan pertumbuhan, terutama di Pulau Seribu.

\section{Prevalensi Anemia pada Balita}

Prevalensi anemia pada balita 2-4 tahun di Jakarta adalah 26,8 \% (tabel 7 dan grafik
1). Prevalensi tertinggi adalah balita di Pulau Seribu yang mencapai $51 \%$. Di wilayah daratan prevalensinya berkisar antara yang terendah $13,7 \%$ di Jakarta Selatan sampai yang tertinggi mendekati $30 \%$ di Jakarta Utara. Dari 5 wilayah kota ada dua wilayah dengan prevalensi anemia di bawah $20 \%$, yaitu Jakarta Selatan dan Jakarta Timur.

Tabel 7

Prevalensi Anemia pada Balita

\begin{tabular}{|l|c|c|c|}
\hline \multirow{2}{*}{ Wilayah } & \multicolumn{2}{|c|}{ Anemia } & Total sampel \\
\cline { 2 - 4 } & $\mathrm{N}$ & persen & \\
\hline Jakarta Utara & 58 & 29.7 & 195 \\
Jakarta Pusat & 55 & 26.1 & 211 \\
Jakarta Selatan & 28 & 13.5 & 207 \\
Jakarta Barat & 56 & 27.5 & 204 \\
Jakarta Timur & 41 & 19.2 & 213 \\
Pulau Seribu & 80 & 51.3 & 156 \\
DKI Jakarta & 318 & 26.8 & 1186 \\
\hline
\end{tabular}




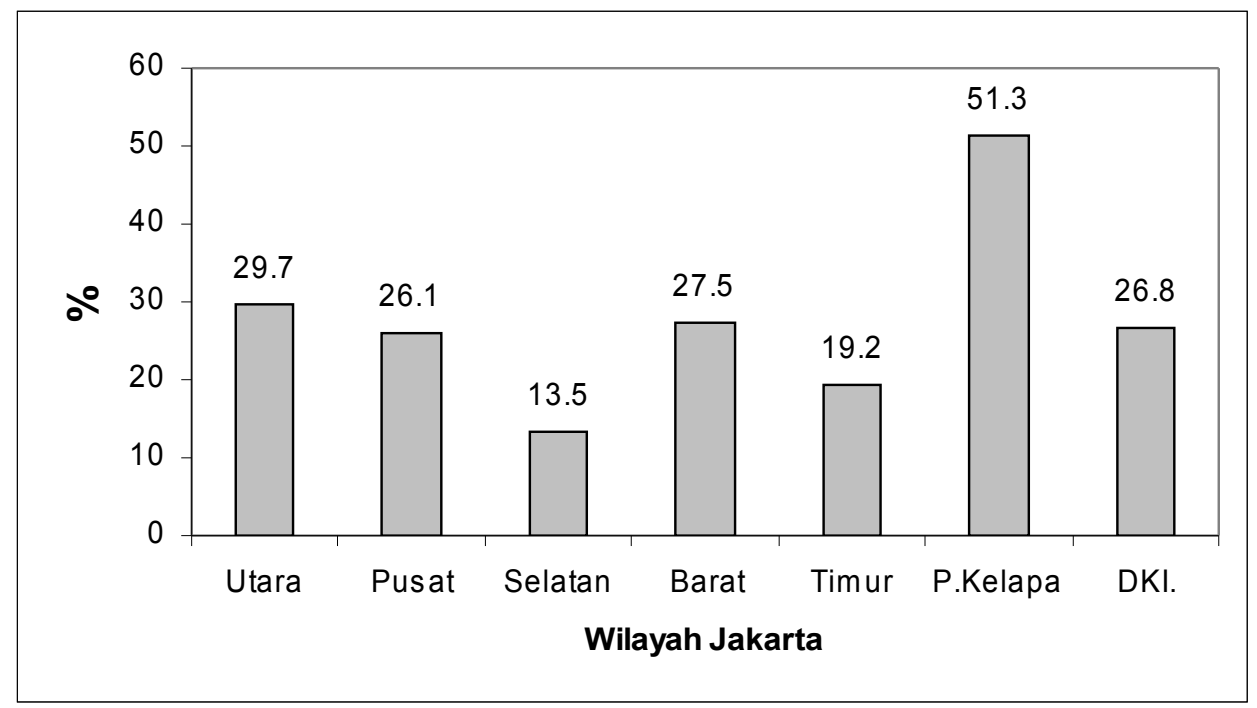

Keterangan:

P. Kelapa $=$ pulau Kelapa

Gambar 1

Prevalensi Anemia pada Anak 2-5 Tahun Menurut Wilayah di DKI Jakarta

\section{Faktor risiko anemia}

Uji regresi logistik ganda dilakukan dengan metoda stepwise secara otomatis peubah penduga yang berkorelasi salah satu tidak akan dimasukkan kedalam model, sehingga tidak terjadi multi colinearity dalam model, yang merusak semua parameter dalam model. Dalam rentang umur antara 2 sampai 4 tahun, semakin tua semakin kecil risiko menderita anemia, setiap tahun penurunan $25 \%$ dibandingkan dengan balita usia 2 tahun. Sedangkan penderita gizi kurang mempunyai risiko $50 \%$ lebih tinggi untuk mendeita anemia dibandingkan dengan anak normal. Balita yang pernah keluar cacing $2-3$ kali selama 1 bulan yang lalu mempunyai risiko menderita anemia hampir 2 kali dibandingkan dengan balita yang cacingan 1 kali. Balita yang ibunya lulus SLTA ke atas mempunyai risiko menderita anemia $37 \%$ lebih rendah dari balita yang ibunya tidak lulus SD. Balita yang bapaknya jadi pegawai negeri dan pegawai swasta punya risiko $33 \%$ lebih rendah untuk menderita anemia daripada balita yang bapaknya bekerja di sektor informal. Balita yang di rumahnya ada kulkas punya risiko menderita anemia 30\% lebih rendah dibandingkan dengan balita yang tinggal di rumah tanpa kulkas. Balita yang mengonsumsi kapsul vitamin A sudah 3 kali mempunyai risiko untuk menjadi anemia 27 $\%$ lebih rendah daripada mereka yang mengkonsumsi kapsul 1 kali atau tidak sama sekali.

Tabel 8

Hasil Uji Regresi Logistik 


\begin{tabular}{|l|c|c|}
\hline \multicolumn{1}{|c|}{ Peubah } & P(signifikan) & Risiko \\
\hline Umur (tahun) & 0.036 & 0.702 \\
Gizi kurang (BB/U) & 0.006 & 1.498 \\
Cacingan lebih dari sekali & 0.005 & 1.872 \\
Ibu lulus SMA & 0.007 & 0.630 \\
Pegawai negeri/swasta & 0.012 & 0.665 \\
Punya kulkas & 0.036 & 0.702 \\
Konsumsi kapsul vit A 3 kali & 0.040 & 0.730 \\
Konstan & 0.546 & 1.170 \\
\hline
\end{tabular}

\section{BAHASAN}

Usia sampel balita yang terliput dalam survei ini adalah anak usia 2 sampai 4 tahun, dimana anak sudah tidak mendapat ASI dan sudah mulai terbiasa dengan makanan keluarga dan bukan makanan pendamping air susu ibu (MPASI). Ini berarti sebagian besar persediaan besi berasal dari konsumsi makanan dan bukan dari ASI atau persediaan saat dalam kandungan.

Dari segi pendidikan dan pekerjaan orangtua sampel berasal dari rumahtangga bukan kelas ekonomi tinggi. Kemungkinan besar merupakan gambaran sebagian besar penduduk Jakarta yang umumnya tidak tinggal di komplek perumahan elit dan menengah.

Prevalensi anemia pada kelompok ini adalah $26,5 \%$. Suatu prevalensi moderat, namun sudah merupakan masalah kesehatan yang harus ditanggulangi. Prevalensi KEP (underweight) sangat tinggi yaitu $30,7 \%$. Prevalensi ini di atas rata-rata prevalensi KEP nasional yang mencapai 27,6 \% (BPS, 2002).

Hasil pemeriksaan dokter menunjukkan bahwa sebagian besar sampel (58 \%) dalam keadaan sakit, yang sebagian besar menderita infeksi saluran pernafasan. Namun prevalensi infeksi saluran pencernaan sangat rendah yang mungkin lebih banyak karena pengaruh musim.

Umur ternyata berpengaruh terhadap prevalensi anemia, dimana semakin tua semakin rendah prevalensi anemia. Tingkat pendidikan ibu secara konsisten berhubungan dengan keadaan kesehatan dan gizi. Untuk DKI Jakarta pendidikan ibu SMA baru dapat memberikan perbedaan terhadap status anemia, sedangkan di Jawa Barat ibu berpendidikan SD pun sudah mengurangi risiko anemia pada ibu hamil (Sumarno dkk, 2002). Pendidikan ibu ternyata berpengaruh terhadap keadaan anemia baik kepada ibunya sendiri maupun kepada anaknya.

Keadaan gizi anak dengan indikator berat badan menurut umur berhubungan erat dengan anemia. Balita dengan status gizi kurang mempunyai risiko $50 \%$ lebih tinggi daripada anak yang bergizi baik. Keadaan ini dapat dimengerti karena gangguan pertumbuhan disebabkan oleh kekurangan berbagai vitamin dan mineral yang diperlukan juga untuk pembentukan $\mathrm{Hb}$. Gangguan pertumbuhan juga dapat diakibatkan oleh kurang energi dan protein yang diperlukan untuk pembentukan $\mathrm{Hb}$.

Semua balita dilaporkan mengeluarkan cacing dalam 1 bulan terakhir. Karena itu dalam analisis logistik balita dibagi 2 kelompok, yaitu kelompok anak yang mengeluarkan cacing hanya sekali dan kelompok yang mengeluarkan lebih dari 1 kali. Dengan asumsi anak yang mengeluarkan cacing lebih dari sekali mempunyai infestasi cacing yeng lebih parah daripada yang hanya mengeluarkan sekali. Analisis logistik menunjukkan bahwa anak yang pernah mengeluarkan cacing lebih dari 1 kali mempunyai risiko $87 \%$ lebih tinggi dari anak yang hanya mengeluarkan cacing 1 kali. Namun kelemahan dengan data yang dilaporkan ibu adalah kemungkinan ibu tidak melihat saat cacing keluar. Terutama bila 
anak dilepas main sendiri. Tidak aneh bila lebih dari $40 \%$ ibu di Pulau Seribu hanya melaporkan bahwa anaknya hanya mengeluarkan cacing 1 kali dalam sebulan. Karena itu walaupun secara konsisten ditemukan bahwa cacingan berpengaruh pada anemia, namun faktor risikonya tidak persis seperti yang dihasilkan dalam analisis di atas.

Yang menarik adalah bahwa pekerjaan ayah berpengaruh terhadap status anemia balita. Bapak yang bekerja sebagai pegawai swasta maupun pegawai negeri mempunyai anak dengan risiko anemia yang lebih rendah dari bapak yang bekerja di sektor informal. Selain faktor ekonomi yang relatif teratur, ada kemungkinan pegawai dengan lebih berpendidikan, lebih banyak membaca, sehingga lebih memahami tentang kesehatan dan gizi. Sehingga keluarga mempunyai perilaku kesehatan yang lebih baik daripada keluarga yang bekerja di sektor informal. Selain itu pekerjaan bapak sebagai pegawai swasta atau pegawai negeri dapat mencerminkan status sosial ekonomi yang relatif lebih baik dibandingkan sektor informal.

Dari faktor-faktor yang berpengaruh terhadap anemia pada balita faktor sosial ekonomi secara konsisten merupakan faktor yang menurunkan risiko anemia. Namun dari semua faktor yang berpengaruh hanya status gizi, cacingan dan konsumsi kapsul vitamin $A$ yang mungkin dilakukan intervensi penanggulangan anemia oleh sektor kesehatan

\section{KESIMPULAN}

Prevalensi anemia pada balita 2-4 tahun di DKI secara umum adalah $26 \%$, suatu prevalensi moderat yang sudah merupakan masalah kesehatan masyarakat.

Kasus kecacingan sangat tinggi (100\%). Anak balita yang pernah keluar cacing 2 kali atau lebih dalam sebulan terakhir mempunyai risiko menderita anemia 1,87 kali lebih tinggi daripada anak yang keluar cacing 1 kali atau tidak pernah.

Keadaan gizi kurang (BB/U) mempunyai risiko 1,5 kali untuk menderita anemia dibandingkan dengan mereka yang dalam keadaan gizi baik menurut umur normal.

Keadaan sosial ekonomi sangat berpengaruh terhadap anemia.

Konsumsi kapsul vitamin A 3 kali menurunkan risiko anemia sampai $27 \%$.

Penanggulangan anemia pada balita harus dilakukan secara komprehensif dari upaya perbaikan gizi, penanggulangan cacingan dan distribusi kapsul vitamin $\mathrm{A}$.

\section{SARAN}

Penanggulangan anemia pada balita harus bersamaan dengan penanggulangan masalah gizi kurang, kecacingan dan distribusi kapsul vitamin A. Perlu dipikirkan penanggulangan anemia melalui perbaikan gizi makro dan mikro.

Perlu penyuluhan anemia dan gizi serta hidup sehat perlu dilakukan dengan cara yang efektif

\section{RUJUKAN}

1. Al-Agha R, Theodorescu I. Intestinal parasite infestation and anemia in primary school children in Gaza Governorates, Palestine. Roum Arch Microbiol Immunol, 2000 ; 59(1-2) : 131-43.

2. Apriyanto R. Pembakuan MP-ASI lokal. Puslitbang Gizi, laporan Penelitian. 2001

3. Avery Gordon B. The Newborn in Nutrition and Growth, Jelliffe and Jelliffe (eds) Plenum Press, New York and London, 1979 ; (2) : 129 - 152.

4. Chandra R.K. Iron and Immunocompetence. Nutr review, 1976; 34: 129

5. Chen Paul CY. Nondietary Factors and Nutrition in Nutrition and Growth ,Jelliffe and Jelliffe (eds) Plenum Press, New York and London, 1979 ; (2) : 47 - 64.

6. Gopalan C dan Jaya Rao KS. Nutrients needs Nutrition and Growth, Jelliffe and Jelliffe (eds) Plenum Press, New York and London, 1979; (2): 9-31

7. Jahari $A B$, Jus'at I, Achadi $E L$ dkk. Penyimpangan positif masalah KEP di Jakarta Utara DKI Jakarta dan di 
Pedesaan Kabupaten Bogor, Jawa Barat dan Lombok Timur, NTB. Laporan penelitian. Kerjasama Lembaga IImu Pengetahuan Indonesia dan UNICEFIndonesia, Jakarta 2000.

8. Nogeira de Almeida CA, Ricco RG, DelCiampo LA, dkk. Growth and hematological studies on Brazilian children of low socioeconomic level. Arch Latinoam Nutr, 2001; 51(3) : 230-5.

9. Oliviera Rejane Santana de, Diniz Ad, Alcides Da Silva, dkk. Magnitude, geographic distribution and trends of anemia in preschoolers, Brazil. RevSaude-Publica, 2002; 36(1) : 26-32.

10. Osorio MM, Lira PI, Batista-Filho M, Ashworth A. Prevalence of Anemia in Children 6-59 months old in the state of Pernambuco, Brazil. Rev-Panam-SaludPublica, 2001; 10(2) : $101-7$.
11.Pribadi Wita dan Saleha Sungkar. Malaria. Fakultas Kedokteran Universitas Indonesia, 1994, pp 53.

12.Price RN, Simpson JA, Nosten F dkk. Factors contributing to anemia after uncomplicated falciparum malaria. Am J Trop Hyg. 2001; 65(5): 614-22.

13. Thomas Brownlie IV, Virginia Utermohlen, Pamela Hinton, and Jere D Haas. Tissue iron deficiency without anemia impairs adaptation in endurance capacity after aerobic training in previously untrained women. Am J Clin Nutr 2004; 79:437 -43

14.Verhoef $\mathrm{H}$, West CE, Ndeto $\mathrm{P}$ dkk. Serum transferrin receptor concentration indicates increased erytropoiesis in Kenyata children with asymptomatic malaria. Am J Clin Nutr, 2001; 74(6): 76775. 